\title{
Discussion on operation flexibility of Zhonggui natural gas pipeline
}

\author{
Ying Song, Liang Feng*, and Wenchen Cao \\ PipeChina Southwest Pipeline Company, China
}

\begin{abstract}
Zhongwei station of West to east natural gas pipeline is connected to the north of Zhonggui line, and Guiyang station of ChinaMyanmar natural gas pipeline is connected to the south, which has important strategic significance in Southwest China. At present, the tie line mainly carries out gas transmission from Zhongwei to Guiyang. Only some pipeline sections and offload stations have reverse transmission function, while all compressor stations have no reverse transmission and pressurization function. In order to evaluate the flexibility of the operation of the Zhonggui line and give some suggestions for the preliminary reconstruction, this paper uses the SPS software to establish the pipeline model and simulate the specific working conditions, focusing on the two working conditions of the intermediate station injection forward transmission and the whole line reverse transmission. Through the simulation, we can get the following conclusions: 1 . When the intermediate station injects forward gas transmission, which compressor station, gas transmission range and joint operation condition with China-Myanmar line need to be started for Zhonggui line; 2 . When the whole tie line is reversed, it is necessary to change the location of the compressor station with the function of reverse transmission and pressurization. Through this study, we can give some reference and evaluation opinions on the lack of flexibility of the current tie line, and also give some reference opinions on the specific implementation of the improvement of the tie line operation flexibility in the future.
\end{abstract}

Keywords: Zhonggui natural gas pipeline; Operation; Flexibility; Judgment; SPS software.

\section{Introduction}

The total length of Zhonggui line is $1613 \mathrm{~km}$, withannualdesignedgas transmission capacity of 15 billion cubicmeters. The line startsfromZhongwei City in Ningxia, passes through six provinces and cities in Ningxia, Gansu, Shaanxi, Sichuan, Chongqing and Guizhou, and ends at Guiyang City in Guizhou[1]. There are 6 compressor stations, 14 gas transmission stations and 73 valve chambers in the pipeline. The pipeline section has poor conditions, complicated terrain and many large drop [2].

\footnotetext{
* Corresponding author: fenglangtc@126.com
} 
The operation of Zhongwei station as follow [3]: the air intake of Zhongwei station mainlyincludes the west section of west to east first line, west to east second line and west to eastthird line, with a total design gas transmission capacity of about 21 million cubicmeters per day; The gas output of Zhongwei station mainlyincludes the east section of ofwest to east first line, west to east second line and west to eastthird line, the Zhonggui line and the Zhongjing line of west to east second line, with a total design capacity of about 290 million $\mathrm{m}^{3} / \mathrm{d}$. It canbeseenfrom the data that the air intake of Zhongwei station isobviouslyinsufficient, and once the reverse transmission of Zhonggui line occurs, the inflow and outflow of Zhongwei station willbebasicallybalanced, soitisnecessary to study the reverse transmission of Zhonggui line.

\section{Analyze the problem}

In view of the aboveproblems, the model of Zhonggui line isestablished by SPS simulation software, and the simulation data are analyzedunderdifferent setting conditions.

\subsection{Introduction of SPS software [4-5]}

SPS simulation software can simulate single fluid, single-phase mixed fluid or batch fluid. SPS software obtains pipeline information from Inprep text file, including all information of physical components. SPS software can not only simulate the normal operation conditions of most pipelines, but also simulate and control the pipeline accident conditions, such as pipeline fracture, equipment failure, etc. SPS software can calculate the flow, pressure, density, temperature and other parameters along the pipeline, and output them in the form of graph or report.

The simulation function of SPS software can be realized in two forms: control sequence operation or interactive operation (boundary conditions can be changed during operation). The initial state can be zero flow state, stored steady state or user-defined steady state.

\subsection{Basic parameters}

1) Natural gasquality (Table 1)

Table 1. Composition of simulatednaturalgas.

\begin{tabular}{ccccccccc}
\hline Composition & $\mathrm{C}_{1}$ & $\mathrm{C}_{2}$ & $\mathrm{C}_{3}$ & $\mathrm{iC}_{4}$ & $\mathrm{nC}_{4}$ & $\mathrm{iC}_{5}$ & $\mathrm{CO}_{2}$ & $\mathrm{~N}_{2}$ \\
\hline Mol\% & 99.65 & 0.065 & 0.03 & 0.008 & 0.002 & 0.015 & 0.072 & 0.158 \\
\hline
\end{tabular}

2) The standard state : pressure $1.01325 \times 105 \mathrm{~Pa}$ (absolute pressure), temperature $20^{\circ} \mathrm{C}$.

3) The absoluteequivalentroughness of pipe innerwallis $10 \mu \mathrm{m}$.

\section{Solve the problem}

The researchisdividedintotwoworking conditions: one is to takeXiangguosigasstorage as the gas source, close the upstream valve of the injection point, and send the injectedgas to Guiyang station, and thenoperate in combinationwith China Myanmar line; Second, China Myanmar gaswillbeused as the gas source for reverse transmission. 


\subsection{Xiangguosi gas storage as the gas source[6]}

The pressure range of Sichuan and Chongqing regioninjectedintoZhonggui line isfrom 4.5 MPa to $5 \mathrm{Mpa}[7]$, the injection point is the Nanbu station or Jiangjin station, and the maximum injection volume is 15 million $\mathrm{m}^{3} / \mathrm{d}$. There are twocompressor stations in the Nanchong and Zunyi, and the pressure to Guiyang station is set at 6Mpa.

Under lowthroughput (from 3 million to 4 million $\mathrm{m}^{3} / \mathrm{D}$ ), the simulation results are shown in Table 2.

Table 2. The simulation results of pressure.

\begin{tabular}{|c|c|c|c|}
\hline Throughput & $\begin{array}{l}\text { The pressure of Nanbu } \\
\text { station }\end{array}$ & $\begin{array}{l}\text { The pressure of } \\
\text { Zunyi station }\end{array}$ & $\begin{array}{l}\text { The pressure of Guiyang } \\
\text { station }\end{array}$ \\
\hline 300 & 4.5 & 4.501 & 4.083 \\
\hline 400 & 4.5 & 4.484 & 3.998 \\
\hline 300 & 5 & 5.01 & 4.559 \\
\hline 400 & 5 & 4.975 & 4.484 \\
\hline
\end{tabular}
withoutpressurization, sopressurizationisneeded. Zunyi station is far awayfrom the injection point, soitis not economical, soonly Nanchong station pressurizationisfeasible.

The followinganalysisisonlyfor Nanchong station compressoroperationscheme:

\subsubsection{When the injection pressure is $4.5 \mathrm{MPa}$}

When the injection volume is 8 million $\mathrm{m}^{3} / \mathrm{D}$, Nanchong station willstartbackflow (about 0.2 million $\mathrm{m}^{3} / \mathrm{D}$ ), as shown in Table 3. Considering the safeoperation of the compressor, the compressor of Nanchong station canbestartedabove 9 million $\mathrm{m}^{3} / \mathrm{d}$.

Table 3. Compressor operating conditions fromNanchong station at 9 million $\mathrm{m}^{3} / \mathrm{d}$.

\begin{tabular}{ccccccc}
\hline station & $\begin{array}{c}\text { Entrance } \\
\text { pressure }\end{array}$ & $\begin{array}{c}\text { Exit } \\
\text { pressure }\end{array}$ & $\begin{array}{c}\text { Number of } \\
\text { compressoroperation }\end{array}$ & power & speed & efficiency \\
\hline Nanbu & 4.5 & & 1 & 5166 & 9945 & 0.825 \\
Nanhong & 4.433 & 7 & & & & \\
Guiyang & 6.058 & & & & & \\
\hline
\end{tabular}

When the injection volume is 12 million $\mathrm{m}^{3} / \mathrm{D}$, as shown in Table 4

Table 4. Compressor operating conditions from Nanchong station at 12 million $\mathrm{m}^{3} / \mathrm{d}$.

\begin{tabular}{ccccccc}
\hline station & $\begin{array}{c}\text { Entrance } \\
\text { pressure }\end{array}$ & $\begin{array}{c}\text { Exit } \\
\text { pressure }\end{array}$ & $\begin{array}{c}\text { Number of } \\
\text { compressoroperation }\end{array}$ & power & speed & efficiency \\
\hline Nanbu & 4.5 & & 1 & 8716 & 11366 & 0.86 \\
Nanhong & 4.355 & 7.5 & 1 & & & \\
Guiyang & 6.011 & & & & & \\
\hline
\end{tabular}

When the injection volume is more than $1200 \mathrm{~W} \times 10^{4} \mathrm{~m}^{3} / \mathrm{D}$, the pressure ratio of a single compressoristoo large to guarantee $6 \mathrm{Mpa}$ at Guiyang station. Therefore, when the injection pressure is $4.5 \mathrm{MPa}$, the flow range requiredcompressoroperation in Nanchong isfrom 9 million $\mathrm{m}^{3} / \mathrm{D}$ to 12 million $\mathrm{m}^{3} / \mathrm{d}$.

\subsubsection{When the injection pressure is $5 \mathrm{MPa}$}

When the injection volume is 7 million $\mathrm{m}^{3} / \mathrm{D}$, Nanchong station willstartbackflow (about 0.2 million $\mathrm{m}^{3} / \mathrm{D}$ ), as shown in Table 5. Considering the safeoperation of the compressor, the compressor of Nanchong station canbestartedabove 8 million $\mathrm{m}^{3} / \mathrm{d}$. 
Table 5. Compressor operating conditions from Nanchong station at 7 million $\mathrm{m}^{3} / \mathrm{d}$.

\begin{tabular}{ccccccc}
\hline station & $\begin{array}{c}\text { Entrance } \\
\text { pressure }\end{array}$ & $\begin{array}{c}\text { Exit } \\
\text { pressure }\end{array}$ & $\begin{array}{c}\text { Number of } \\
\text { compressoroperation }\end{array}$ & power & speed & efficiency \\
\hline Nanbu & 5 & & 1 & 334 & 8338 & 0.82 \\
Nanhong & 4.953 & 6.9 & & & & \\
Guiyang & 6.071 & & & 15 & & \\
\hline
\end{tabular}

When the injection volume is 15 million $\mathrm{m}^{3} / \mathrm{D}$, as shown in Table 6 :

Table 6. Compressor operating conditions from Nanchong station at 15 million $\mathrm{m}^{3}$ / $\mathrm{d}$.

\begin{tabular}{ccccccc}
\hline station & $\begin{array}{c}\text { Entrance } \\
\text { pressure }\end{array}$ & $\begin{array}{c}\text { Exit } \\
\text { pressure }\end{array}$ & $\begin{array}{c}\text { Number of } \\
\text { compressoroperation }\end{array}$ & power & speed & efficiency \\
\hline Nanbu & 5 & & 1 & 10147 & 11399 & 0.857 \\
Nanhong & 4.801 & 8 & & & & \\
Guiyang & 6.018 & & & & & \\
\hline
\end{tabular}

Therefore, when the injection pressure is $5 \mathrm{MPa}$, the flow range requiredcompressoroperation in Nanchong isfrom 8 million $\mathrm{m}^{3} / \mathrm{d}$ to 15 million $\mathrm{m}^{3} / \mathrm{d}$.

\subsubsection{China-Myanmar line and zhonggui line joint operation[8]}

The gas volume from China-Myanmar line is 10 million $\mathrm{m} 3 / \mathrm{D}$, the pressure is $8 \mathrm{MPa}$. Zhonggui line injection flow is 10 million $\mathrm{m} 3$ / d. Download 2.5 million $\mathrm{m}^{3} / \mathrm{d}$ in Nanning, 0.5 million $\mathrm{m}^{3} / \mathrm{d}$. in Lufeng, 1 million $\mathrm{m}^{3} / \mathrm{d}$. in Guigang, surplus in Guangzhou,andmake sure the download pressure is no lessthan $5 \mathrm{MPa}$, as shown in Table 7.

Table 7. The pipeline conditionfrom China-Myanmar line.

\begin{tabular}{|c|c|c|c|c|c|c|c|}
\hline station & volume & $\begin{array}{l}\text { Entrance } \\
\text { pressure }\end{array}$ & $\begin{array}{c}\text { Exit } \\
\text { pressure }\end{array}$ & $\begin{array}{c}\text { Number of } \\
\text { compressoroperation }\end{array}$ & power & speed & efficiency \\
\hline Ruili & +1000 & & 8 & & & & \\
\hline Baoshan & & 7.218 & & & & & \\
\hline Lufeng & -50 & 6.873 & & & & & \\
\hline Guiyang & +1000 & 6.54 & 7.7 & 1 & 4358 & 3585 & 0.787 \\
\hline Hechi & -100 & 7.2 & & & & & \\
\hline Guigang & -250 & 6.477 & & & & & \\
\hline Guangzhou & -1600 & 5.046 & & & & & \\
\hline
\end{tabular}

The conclusions are as follows: 1. Considering the economy and reliability of the operation of the Zhonggui line, itissuggestedthat the injectedgasshouldbebetween 9 million $\mathrm{m}^{3} / \mathrm{D}$ and 13 million $\mathrm{m}^{3} / \mathrm{D}$, and Nanchong compressor station shouldbeoperated; 2 . Guiyang compressor station shouldbeoperatedwhen China-Myanmar line and zhonggui line joint operation.

\subsection{China-Myanmar gas as gas source reversed}

Guiyang station is the first station when reverse transmission, and set the exit pressure of Guiyang station is $9.8 \mathrm{MPa}$. while the upperlimit of the download pressure at Tongliangis 7.5MPa, and the guaranteed pressure at Zhongwei station is $6 \mathrm{MPa}$. The download volume at Tongliangis 10 million $\mathrm{m}^{3} / \mathrm{d}$, and the restistransported to Zhongwei station.

According to the above conditions, the output range to Zhongwei station and the compressor station whichneedreform.

The simulation results show that the pressure of Tongliang station islessthan $7.5 \mathrm{MPa}$ withoutpressurization at Guiyang-Tongliang section, and transportation capacity of this section should not belessthan 27 million $\mathrm{m}^{3} / \mathrm{d}$. 
3.2.1 The download capacity of Tongliangstaion is 10 million $\mathrm{m}^{3} / \mathrm{d}$, and that of Zhongwei station is 20 million $\mathrm{m}^{3} / \mathrm{d}$, as shown in Table 8

Table 8. The downloadcapacityof Tongliang and Zhongwei.

\begin{tabular}{cccccccc}
\hline station & volume & $\begin{array}{c}\text { Entrance } \\
\text { pressure }\end{array}$ & $\begin{array}{c}\text { Exit } \\
\text { pressure }\end{array}$ & $\begin{array}{c}\text { Number of } \\
\text { compressoroperation }\end{array}$ & power & speed & efficiency \\
\hline Guiyang & +3000 & & 9.8 & & & & \\
Tongliang & -1000 & 6.938 & & 2 & 12109 & 9069 & 0.822 \\
Nanchong & & 6.48 & 9.8 & & & & \\
Zhongwei & -2000 & 5.96 & & & & \\
\hline
\end{tabular}

3.2.2 The download capacity of Tongliangstaion is 10 million $\mathrm{m}^{3} / \mathrm{d}$, and that of Zhongwei station is 30 million $\mathrm{m}^{3} / \mathrm{d}$, as shown in Table 9

Table 9. The downloadcapacityof Tongliang and Zhongwei.

\begin{tabular}{|c|c|c|c|c|c|c|c|}
\hline station & volume & $\begin{array}{l}\text { Entrance } \\
\text { pressure }\end{array}$ & $\begin{array}{c}\text { Exit } \\
\text { pressure }\end{array}$ & $\begin{array}{c}\text { Number of } \\
\text { compressoroperation }\end{array}$ & power & speed & efficiency \\
\hline Guiyang & +4000 & & 9.8 & & & & \\
\hline Zunyi & & 7.673 & 9.8 & 2 & 11635 & 7479 & 0.86 \\
\hline Jiangjin & & 7.39 & 9.3 & 2 & 11895 & 7902 & 0.837 \\
\hline Tongliang & -1000 & 7.438 & & & & & \\
\hline Nanchong & & 6.437 & 9.5 & 2 & 15198 & 9565 & 0.863 \\
\hline Guangyuan & & 7.544 & 9.8 & 2 & 10542 & 7844 & 0.859 \\
\hline Tianshui & & 6.967 & 9.8 & 2 & 13399 & 8986 & 0.863 \\
\hline Zhongwei & -3000 & 6.26 & & & & & \\
\hline
\end{tabular}

The conclusions are as follows: 1. In order to makeZhonggui line have the function of whole line reverse transmission, itisnecessary to reform at Nanchong compressor station for reverse transmission of pressurization transformation; 2. If reform at the compressor stations of Zunyi, Jiangjin, Nanchong, Guangyuan and Tianshui, itcanbeguaranteed the reverse transmission capacity 30 million $\mathrm{m}^{3} / \mathrm{d}$, whichbasicallyensuring the balance of gas flow in and out of Zhongwei station.

\section{Conclusion summary}

1) Xiangguosigasstorage as the gas source, itissuggestedthat the injectedgasshouldbebetween 9 million $\mathrm{m}^{3} / \mathrm{D}$ and 13 million $\mathrm{m}^{3} / \mathrm{D}$, and Nanchong and Guiyang compressor station shouldbeoperated.

2) China-Myanmar gas as gas source reversed, In order to makeZhonggui line have the function of whole line reverse transmission, itisnecessary to reform at Nanchong compressor station for reverse transmission of pressurization transformation. If reform at the compressor stations of Zunyi, Jiangjin, Nanchong, Guangyuan and Tianshui, itcanbeguaranteed the reverse transmission capacity 30 million $\mathrm{m}^{3} / \mathrm{d}$, whichbasicallyensuring the balance of gas flow in and out of Zhongwei station.

\section{References}

1. JIANG Wanquan, QUAN Taifeng, XU Ying. naturalgas transport network forming to protect the pattern [J].PetroChina news, 2013.10.29 (001): 14-18 
2. WEN Xiaofeng, XU Chenchen, AN Yao, et al.CommissioningTechnology of .Zhongwei - Nanbu section in Zhong-Guigas pipeline project [J]. Pipeline Technology and Equipment, 2014.2: 14-18

3. Correspondent of "Gas\&Heat", The Introductionof middle of the West-East gas pipeline projectthreelines [J], Gas and heat, 2012.8: 9

4. ZHENG Yunping, XIAO Jie, SUN Xiao, et al. Application and recognize SPS simulation software in gas pipeline [J]. Natural GasIndustry, 2013,33(11):104-109.

5. FENG Liang. The optimization and simulation on the operation of line- 2 and line- 3 of shaanxi-Beijing gas pipeline system [D]. China Petroleum University (Beijing), 2013:199.

6. HU Lianfeng, LI Qiao, LIU Dong, et al.Peak season underground gas storage injection and production scale design -In Sichuan and Chongqing gas fields with Temple underground gas storage project design as an example [J].Gas industry, 2011, 31 (05): 96-98.

7. HUANG Yan, SHE Chaoyi, TANG Xiaohu. Research and Application of Gas drainage gas technology in Sichuan Basin [J]. drilling technology, 2008,31 (5): 66-69,72

8. TIAN Gong, Sino-Myanmar gas pipeline fully operational [J] gas industry, 2013.10: 11 